\title{
Civic virtue and values teaching in a 'post-secular' world
}

\author{
Carol Vincent, UCL Institute of Education
}

Revised Paper submitted to Special Issue of Theory and Research in Education March 2018

\author{
Professor Carol Vincent \\ UCL Institute of Education \\ 20 Bedford Way \\ London WC1H OAL \\ carol.vincent@ucl.ac.uk
}




\begin{abstract}
Drawing on empirical data, this paper makes a contribution to knowledge through bringing together the apparently disparate elements of contemporary education policy, religion, civic virtue, and values teaching, in particular the teaching of 'fundamental British values'. I illustrate, through a discussion of the linkages between these elements, how religion remains a strong influence on contemporary education policy, both explicitly with regard to the integration of Muslim 'others' and implicitly through the growing popularity of values education in schools. In order to develop this argument, I first outline the extent to which Christianity, often de-theologised, shapes normative Western European values and permeates apparently secular spaces. Second, I identify some school responses to the British values policy and note the importance of the political and social context informed, I argue, by acute anxiety around Islam and extremism. Third, through the discussion of one particular school site, I identify the trend towards emphasising values education in secular schools, and the implicit religious undertones within this. I suggest that we can understand this trend as an instance of the post-secular where religious influences remain strong in apparently secular places, but argue that there are limitations to such an approach to values education in terms of increasing pupil voice and agency.
\end{abstract}




\section{Civic virtue and values teaching in a 'post-secular' world}

\section{Introduction}

This paper discusses the relationship between values teaching - and the teaching of fundamental British values in particular - religion and civic virtues, drawing on an initial analysis of data from an on-going project funded by the Leverhulme Trust ${ }^{1}$. It draws attention to the growing focus on teaching values in schools. Values are the traditional arena of faith schools - a theme of this Special Issue - as different faiths define for children how to treat others and live a 'good' life. However, the current wave of values teaching that I discuss here affects faith and non-faith schools and I am going to concentrate on two forms: one, the government's directive to schools to promote 'fundamental British values', and two, the rise amongst schools of value/moral/character education (variously named). I suggest here that we cannot understand either of these initiatives - neither overtly religious - without understanding how they are pervaded by religion, especially Christianity, although often in a de-theologised form; thus, I shall consider 'how the theological still inhabits the putatively secular' (Golder 2007 p.170-1, see below). Furthermore, I conclude by arguing that neither of these forms of values teaching provides a thorough civic education.

\section{Data collection}

Data are drawn from a project focusing on how teachers understand and promote British values. The Department for Education (DfE) (2014) defines 'fundamental British values' - which English schools are required to promote - as democracy, rule of law, individual liberty, mutual respect and tolerance for those of different faiths ${ }^{2}$. The school's inspectorate, Ofsted, include both how schools promote those values and how they prepare pupils for 'life in modern Britain' as part of their inspection (Ofsted 2016 para 138, 139).

\footnotetext{
1 A Major Research Fellowship running October 2016-September 2018.

2 Different understandings of this policy variously identify four or five values, with the latter decoupling 'mutual respect' and 'tolerance'.
} 
At the time of writing, I have compiled a total data set of 54 interviews and 43 observations. The majority of these ( 38 interviews with teachers and 40 observations) are from nine case study schools (four primary and five secondary) with different pupil demographics in terms of social class and ethnicity. These schools are mostly within Greater London, although three are in other parts of the country and they include academies and maintained schools, with one being a faith school. Additionally, in order to reach a wider range of schools, I conducted one-off interviews with senior leaders at 6 schools, including two faith schools. I also spoke with ten other individuals who have a professional interest in the British values policy (e.g. faith school advisers, teacher union representatives). Finally I also attended three training sessions/conferences on the teaching of British values. For the observations, I asked teachers to identify lessons/assemblies they felt illustrated the promotion of British values. This led to me observing a very wide range of activities from primary pupils making videos about good manners, through secondary school pupils dancing with senior citizens at a school-hosted coffee morning, to pupils listening to Holocaust survivors. This range is indicative of the variation in teacher practice further discussed below. However, given the limitations of space and the relatively early stage in analysis at which this paper was written, I offer here a brief insight into some school practices and responses, but then go on to focus on one particular school site where values education was most developed.

\section{Values, civic virtue and Christianity}

I intend to highlight aspects of the complex inter-relationships between religion, values, and civic virtue as revealed through the prism of the British values policy, and teachers' responses to that policy. The mandatory promotion of democracy, rule of law, individual liberty, mutual respect and tolerance might be expected to generate renewed emphasis on civic virtue. Civic virtue is defined here as focusing in particular on the dispositions for participation in political processes and civil society, in the form of capacities and desires to debate, reflect, listen, persuade without coercion (Ben-Porath 2013, Macedo 2000, McClain 2001, Arthur et al 2017). However, I suggest that renewed emphasis on civic virtue is not necessarily forthcoming; rather that values education offers particular narratives for pupils to 
follow, and moreover that those apparently secular western liberal narratives and spaces are permeated by religion (namely, Christianity). Golder, discussing Foucault, argues that the 'western political imaginary' depends on 'the continuance of the sacred (albeit in an altered form)'.

"Our" concepts such as sovereignty, law and nation depend upon a disavowed theological dynamic even while laying claim to secular status (the claim to being secular is a discursive condition of possibility for political action in the liberal public sphere, while the sacred/religious/theological is relegated to a private sphere of belief). [....] This avenue of analysis thus focuses upon the philosophical dynamic of foundational concepts of modern law and politics in an effort to demonstrate how the theological still inhabits the putatively secular (Golder 2007 p.170-1).

Given the historic role and continued influence of faith-based providers of education, dominated, of course, by Christianity, it is perhaps unsurprising that religion in the 'liberal public sphere', whilst overtly 'relegated to the sphere of private belief' as Golder comments, continues to influence state education policy and practices in school, in ways that are often, but not always, unremarked and unrecognised. The paper contains examples of both the explicit and implicit influence of religion on contemporary education policy and practices. I argue, first, that the British values policy came into being as part of a growing concern about difference, cohesion and the restriction of, not simply extremist, but also conservative, versions of Islam. In this example, religion is much remarked upon, and explicitly intertwined. Second, and with regard to values education more broadly, I illustrate my discussion with reference to pedagogy at a non-faith primary school that has subsumed the requirement to promote British values within its own school-based values work. Religion is unremarked and implicit here, and its identification emerges from the first stage of my on-going analysis. Using this case as one example of the growing ubiquity of values education, I will consider what McClain (2001) refers to as a 'spill-over' between 'personal and democratic selfgovernment'. I shall argue that values education focuses on 'personal self- 
governance' to a degree that appears to marginalise 'democratic self-governance' or civic virtue. In illustrating and discussing school practices and pedagogies that promote these two forms of values teaching - British values and values education more broadly - I conclude that despite their apparent potential to promote civic virtues, my data suggest that both forms of values education often act to undercut the promotion of 'critical reflection', a fundamental part of civic virtue (Macedo 2000, Gutmann 1994).

\section{The post-secular public sphere}

The explicit, and also implicit and often de-theologised influence of Christianity on social and political norms has been identified by commentators in several disciplines, including philosophy, sociology, education, and law. I cited Golder above. Similarly Casanova notes that "secular" and "Christian" cultural identities are intertwined in complex and rarely verbalized modes among most Europeans' (2006 p.14). Writing from a legal perspective, Jivraj makes a similar point, emphasizing that the de-theologised influence of Christianity may often pass unnoticed.

Religion can circulate in juridical discourse ... as neutral, secular and universal when associated with Western de-theologised Christian values and citizenship [...] Religion, or rather Christian values, underpinning universal or common values, can be understood as co-imbricated with notions of the secular. Bhandar (2009) has argued that Christianity's de-theologised influence is maybe too subtle in its imbrications with secularity and universalising values discourse to even be noticed' (Jivraj 2013 p.322, 324)

Likewise, Hemming cites Mellor in describing social organisation in Western societies "'as complex, multi-layered phenomena with religious aspects that are so deeply rooted that they not only tend to be un-acknowledged, but may also be expressly denied" (Mellor 2004: 5)' (Hemming 2015 p. 21). Such arguments present a challenge to straight-forward accounts of the increasing secularisation of western European societies. Habermas notes that 'In these [western European] societies, religion maintains a public influence and relevance, while the secularistic certainty 
that religion will disappear worldwide in the course of modernization is losing ground' (2008 p.21). The term 'post-secular' is contested, and for reasons of space, I will not review all the arguments here - although they often revolve around the degree to which secularisation could be said to have been achieved (Hemming 2015) - but instead point to Dillon's useful clarification in his comment on Habermas' paper: 'In my view, the term "post secular" is more theoretically robust if we can use it to help us understand the more general relevance of religion as a public cultural resource in all modern democratic societies regardless of their varying levels or degrees of secularism and secularization' (2012 p.258). With regard to education in particular it is important to note that there are deep connections (or genealogical roots) between religion and the development of formal education (see Bailey 2015 for discussion). Bailey cites Hunter:

By the middle of the eighteenth century in most western European states two different and autonomous rationales for educating the population lay side by side ... From the political rationality and 'expert systems' of the emerging governmental State emerged the imperative for a bureaucratically organised system of mass education ... The other programme emerged from the historic efforts of the reformed Protestant and Catholic churches to Christianize lay populations, through a dedicated transfer of spiritual discipline into the routines of daily life (Hunter 1996, p. 161).

With these arguments in mind, I continue by considering two ways in which religion permeates both the British values policy itself and school practices around values education more broadly. One of these modes of permeation is relatively explicit and overt, the second emerges, as stated above, from my analysis.

\section{British values, anti-extremism, and Islam}

The explicit permeation of religion informs the context for and close links between the British values policy and anti-extremism and anti-radicalisation policies, which many commentators have critiqued as being directed primarily and excessively at Islam (e.g. Meer 2010, Husband \& Alam 2011, Coppock \& McGovern 2014, Mac an 
Ghail \& Haywood, 2017, Panjwani et al 2018). The DfE's definition of British values in its guidance for schools is taken from the 2011 anti-extremist Prevent strategy ${ }^{3}$ The promotion of British values in schools publicly crystallised as a policy in a debate in the House of Commons in June 2014, when the then Secretary of State for Education, Michael Gove, promised that the government 'will put the promotion of British values at the heart of what every school has to deliver for children' (Hansard 2014 vol 582, col 266).

The debate at which Gove was speaking was discussing the Trojan Horse affair in Birmingham, where several schools were subject to accusations of infiltration and 'Islamification' by conservative Muslims who sought, for example, to segregate boys and girls within these secular state schools ${ }^{4}$. The Trojan Horse Affair is difficult to unravel. Some commentators argue that conservative Muslim practices - 'the desire of parents to retain traditional values and a sense of security in a disorientating world' (Arthur 2015 p.318) - were conflated by Ofsted, the various investigations into the affair, and the media, with what the Muslim Council of Britain called a 'supposed ideology and agenda to Islamise secular schools' (cited in Arthur 2015 p.319), and others point to school mismanagement (e.g. Poole 2016). On the other hand, Holmwood and O'Toole (2018), in a detailed critique, argue that in the school at the heart of the case - which had a $98.9 \%$ Muslim population - the expression of Islamic religious identity (e.g. through collective worship), was considered problematic in itself, whereas the general requirement for secular schools to have collective worship of a 'broadly Christian character' is not.

The link between British values, schools and fears of radicalisation and extremism reaches back beyond the Trojan Horse affair. Earlier New Labour governments emphasised the importance of community cohesion, as a response to the perceived

\footnotetext{
${ }^{3}$ https://www.gov.uk/government/publications/prevent-strategy-2011

4 There were three separate Trojan Horse investigations, one for the DfE claiming evidence of 'an intolerant and aggressive Islamist ethos'. The 2015 Education Select Committee found that apart from one incident in one school, there was "no evidence of extremism or radicalisation" in any of the schools involved.

(https://www.publications.parliament.uk/pa/cm201415/cmselect/cmeduc/473/47303.htm). Disciplinary procedures against senior teachers at the schools were dropped in May 2017 (http://www.bbc.co.uk/news/uk-england-birmingham-40094333).
} 
need to bolster social cohesion and the apparent failure of multicultural policies to do so (Garbaye \& Latour 2016, Alam \& Husband 2013). Thus community cohesion policies came to prominence as a response to civil disturbances in the North of England in the early 2000s, and were, Husband and Alam (2011) argue, the latest manifestation of an often contentious policy history of state responses to diversity, designed particularly to encourage the increased integration of Asian-origin, often Muslim, populations who were understood to lead 'parallel lives' (Cantle 2001), marked by an excess of insular bonding social capital and too little bridging social capital (Alam and Husband 2013 p.243 citing McGhee). ${ }^{5}$ After 9/11 and the 2005 London tube bombings, the prevalent state concern was with preventing extremism and terrorism, and Husband \& Alam (2011) outline how community cohesion and counter-terrorist policies quickly became conflated at the level of policy enactment (also O'Toole et al 2016). Schools were brought into this securitization matrix implicitly through the British values policy in 2014, and explicitly through the Prevent duty in 2015 (which states that teachers are to have "due regard to the need to prevent people from being drawn into terrorism": s. 26, Counter-Terrorism and Security Act 2015).

Thus, the British values policy in its current iteration requires schools to disseminate particular values that are understood to both lessen the risk of extremism and increase social cohesion around these shared values. Their mandatory promotion in schools can be understood as a response to heightened public alarm around terrorism, and xenophobia around migration, and as part of a series of responding measures which include Prevent, citizenship tests, and integration oaths (the latter recommended by 2016 Casey review) that are designed to reassure 'the "neurotic citizen" (Isin 2004) that the boundaries around the nation and who is to be considered a member of the nation are sufficiently high and arduous' (Byrne 2016 p.12).

\footnotetext{
5 Ted Cantle understood his description of 'parallel lives' to refer equally to both the white and Asian origin populations in Bradford.
} 
In setting such boundaries, the influence of Christianity is visible. For example, Jivraj (2013 p.319) notes that ex-Prime Minister Cameron, in his 2011 speech, on the 400 ${ }^{\text {th }}$ anniversary of the King James Bible, deemed that 'just as our language and culture is steeped in the Bible, so too is our politics'. He continued by arguing that 'we' needed 'a lot less of the passive tolerance of recent years and a much more active, muscular liberalism' (repeating his earlier 2011 speech in Munich). The King James' Bible speech presented religious extremism as an example of 'moral collapse' arising from segregated communities whose behaviour ran counter to 'our' values, whilst the Bible was portrayed as a source of 'values and morals which make Britain what it is today. Values and morals we should actively stand up and defend'. (Cameron 2011).

This focus on the benefits of 'shared' values, 'muscular liberalism', and the demise of 'passive tolerance' appears to translate, in practice, to an intense state gaze that is brought to bear on non-Christian, particularly Muslim, faith schools. As one headteacher of a state-funded Muslim primary school said:

I am the only head teacher in probably [the local authority], or in the [local partnership], who has picked up that self-evaluation [document] around Prevent and extremism, and went through it religiously to make sure that I have got every evidence. [...] Even though our school is the best performing school in [the area], however the fears that I have, none of the head teachers [in the partnership] share that. [...] [The teaching of British values] is not a focus [for Ofsted] when it comes to non-Muslim schools. (Head-teacher, state-funded Muslim faith school, urban area, largely working-class population. See also respondent in Meer's 2010 study p.143).

This head-teacher feels that Muslim schools are presented as a threat to community cohesion in a way in which secular or established Christian Church of England or 
Catholic schools are generally not ${ }^{6}$. Teachers at four other schools in my research that had Muslim majorities noted that Muslim pupils felt stigmatised by media coverage and conflation of 'Muslim' with extremist behaviour. One head-teacher himself also conflated these terms, assuming a 'hidden agenda' motivating parents in his Parent-Teacher Association (see Vincent 2017). Relatedly, Jivraj (2013) notes the 'othering' of non-Christian faiths.

In short, whilst the normative Christian underpinning of universal, secular values circulates as a discourse of good citizenship, 'values talk conceals the hierarchy', racialisation and orientalist configurations expressed about non-Christian-ness (Razack, 2008, p. 8; Goldberg, 1993, p. 63)' (Jivraj 2013 p.333).

Thus, schools are working within a context in which the signifier of 'Muslim' has come to homogenise, and present as 'other', a highly differentiated population. A denigrating collective identity (Appiah 1994 p.160) acts to question that group's ability to claim belonging in the public sphere, and indeed Meer argues that the 'claim making' [in the public sphere] of Muslims within Western, predominantly Christian states, has been characterised as specifically ambitious and difficult to accommodate' (Meer 2010 p.19). To assert an integrationist perspective of 'shared values', as the British values policy does, across the uneven terrain of belonging, is likely to work, not to integrate, but rather to emphasise the inequalities in religious recognition and respect (Morgan 2016).

\section{School responses to the British values policy}

Policy sociologists illuminate the way in which policy identifies particular phenomena as problems - 'the target of social regulations at any given moment' (Foucault 1983, lecture 6 p.2, cited in Ball 2013 p.14) - so the existence of the British values policy suggests that the values pupils hold or do not hold are positioned as

\footnotetext{
${ }^{6}$ Muslim schools in East London and elsewhere have been criticised by Ofsted for their promotion of British values as have some Catholic, evangelical Christian, and Jewish schools (see Vanderbeck \& Johnson 2016), but the former have received more attention (Holmwood and O'Toole 2018)
} 
potentially problematic and requiring state intervention. The nature of that 'social regulation' requires further examination. Ball (2013) notes that Foucault's concerns with both the disciplining of the individual body (through, for example, the form of values education in Southern School discussed below), and the regulation of the population (through, for example, the imposition of 'shared' values) come together in schooling which 'is one point on the "crossroads where that power over and invested in, individual bodies and populations would converge in technologies of discipline and regularization" (Stoler 1995 p.83)' (Ball 2013 p. 54). However, this is not to argue that the British values policy is straightforwardly a form of discipline, as practice is 'contradictory, incoherent and contested' (as O'Toole 2016 says in relation to Prevent). The policy is a loose, open, and enabling one in terms of defining appropriate practice. Ball et al (2012 p.94) argue that such policies (theoretically) present teachers with a variety of intelligible, acceptable responses, and thus opportunities for creativity, sense-making, and personal commitment.

However, given the pressures under which they work - for teachers are having to respond to multiple policies and demands at any one time (Ball et al 2012) - and given the absence of detailed guidance, some schools have understandably responded with an approach to British values that appears to tick the right the box. One head-teacher who had been involved in a public critique of the policy described a colleague's response.

I spoke to one head-teacher and he said, 'I don't know why you are fussing about this...', he said, 'we have laminated all the key words from the British values document, put them up round the corridors and we are done'....Because it just got it out of his way, you know (Seaside School, suburban area, largely White British, middle-class population).

One highly visible response (see Vincent 2017 for discussion of others) includes posters, often replete with union jacks, either listing the DfE-defined British values or focusing on a specific British value (e.g. a display on the Houses of Parliament for democracy), and, particularly around the time of the Queen's $90^{\text {th }}$ birthday, 
activities related to the monarchy. One teacher at a case study primary school in London with a majority minority ethnic population, described her school's celebrations for the Queen's birthday,

We never used to have like community celebrations and things like that, when we had the Queen's birthday last year, we made it a big thing in our school [...] we organised like a party, like a tea party and then each class was asked to sing a song [...] mainly British songs that kindles patriotism or something like that [..] And we did mugs as well....We painted [them] and we did loads of activities related to the Queen's birthday and we had a lunch especially for the Queen,...it was quite nice, a fun day for the whole school, yes it was really nice (Teacher, Newton Primary School, urban area, working class population largely of South Asian heritage).

Monarchy, of course, is not on the list of British values, and such celebrations evidence the confusion in some school sites between the British values and symbols commonly associated with Britain (with one commercial provider suggesting 'make your own union jack bunting'). It is a satisficing approach that lends itself to a certain amount of stereotyping around 'Britain' and 'British' symbols and customs, which are made to 'stand for' values (Arthur 2015, Struthers 2017). Although some research suggests teachers' discomfort with teaching patriotism (e.g. Jerome and Clemitshaw 2012), the abundance of union jacks on display in schools suggests that many teachers feel comfortable with a patriotism-lite, featuring the Queen, and the achievements of famous (often white and male) British people. This is the reinvention of an imaginary past (e.g. celebrations of Empire Day). Clearly such activities suggest a particular framing of 'nation' and 'citizens' that focuses on celebrating popular symbols and traditions. What such an approach does not include is any sense of engaging with or problematizing the British values themselves.

The British values aim for consensus, at the expense of any recognition that they can be subject to differing interpretations. 'Tolerance' for example is a value that can appear limited, 'an intermediate between whole-hearted acceptance and 
unrestrained opposition' (Scanlon 2003 p.187), and may also be dependent on the generosity of those doing the tolerating, especially when uncoupled from mutual respect, as in some local versions of the British values policy. Additionally, work in political philosophy argues that inherent in the concept of toleration is the power not to tolerate (e.g. Horton 1996, p. 28). However, different potential interpretations of the British values were only infrequently raised by the respondents in my research. Thus, the British values policy appears to be an example of the state asserting a 'benign universalism' (Husband \& Alam 2011 p.219). Whilst the values identified as British values have a rather wider import beyond Britain and a history rooted in western liberal thought, the direct assertion of them as consensual and unproblematic 'British' values appears, given the contemporary political and social context, as a crude attempt to integrate 'others', especially Muslim others. This is a form of 'polarised identity politics' (Poole 2016 p.3). The effectiveness of the policy as a mechanism of integration is undercut to a degree, by its loose form, and the different ways in which teachers are interpreting it (see Vincent 2017 for more detail on different approaches). However, one point of common agreement across the interviewees was the low status and limited lesson time available for discussion and debate with pupils. Thus, critical reflection, engagement and discussion of the values was not generally foregrounded.

\section{Values and virtues}

The second example of religion permeating the data that I wish to discuss in the remainder of this paper, is not explicitly to do with religion, but concerns the growth of values education in secular schools. My point here, as Hemming (2015) says, is to 'break open' an overtly secular space and identify the religious influences. A strong values framework is of course traditionally associated with faith schools, and this is ground that faith schools are keen to claim, with advisers with whom I spoke, suggesting, if not a moral vacuum, then a downplaying of morals and values in secular schools.

And the danger is that when you remove the teaching of faith education or religious education or you downgrade it and that is certainly what has 
happened in some schools, the net result is that some of the values that automatically would have been taught actually fall by the wayside. (Jewish education adviser)

However values education, also referred to as virtue, or moral, or character education (the latter term is used by the Jubilee Centre at Birmingham University), is growing in popularity in the secular schools of the US (e.g. Smagorinsky \& Taxel 2005), the UK (e.g. Arthur et al 2017), and other European countries such as Italy (e.g. Maccarini 2016); also in Canada (e.g. Winton 2007), Australia (e.g. Cranston et al 2010), Singapore (Tan and Tan 2014) and elsewhere. Walker et al's definition of character education encompasses other related terms; that is, as 'broadly any approach to moral education that foregrounds the cultivation of moral character and moral virtue' (Walker et al 2015 p.79). In its more conservative forms it has been criticised for its excessively individualistic bias and focus on 'kid fixing' (Walker et al 2015 p.85, Smagorinsky \& Taxel 2005 ). However, I want to draw out the often unacknowledged influence of religion ${ }^{7}$ on values education, and turn to consider what practices school-based values education includes.

Southern Primary is a non-faith, local authority-maintained school serving a deprived area (FSM ever $\left.44 \%^{8}\right)$. Run by an ethnically diverse staff team, it is judged by Ofsted as Outstanding. Southern adopted a distinctive (but not unique) approach to British values, which was to subsume the promotion of these values into its own values framework. These values - delight, together-ness, mutual respect, resolution, quality, responsibility, kindness (the terms have been slightly changed to preserve anonymity) - underpin staff and student behaviour. Recently, the school started to explicitly teach the children the school values in turn, and assess them on their ability to demonstrate aspects and degrees of the desired behaviours. The children seemed to absorb the prescribed messages effectively. For example, during the

\footnotetext{
${ }^{7}$ It is important to note that secular schools are still required to teach RE and have an assembly of a 'broadly Christian' nature (Holmwood \& O’Toole 2018).

8 'FSM ever' is the percentage of pupils that have been or are eligible for Free School Meals at any point in the last six years. The national average is $25.4 \%$.
} 
focus on 'resolution', one display featured the writing of Y6 (10/11 year olds) children in response to the question: 'Why will YOU be on the front cover of a newspaper?'. The children's accounts of their imagined future success include the following:

'The key value of [resolution] helped [girl] aged 20 become the person she wanted to be in life because she persevered'

'He knew a negative attitude would never allow him to achieve his goals'.

I observed several of the values lessons that took a similar format: a stimulus (a story or a video clip), a discussion of the meaning of that particular value, and then one or more tasks, usually in small groups. So, for example, in a lesson on the importance of resolution and determination with $Y 4$ (8-9 year olds), the children are shown a clip of an athlete injuring his hamstring but finishing the race, although clearly in pain. The value set is then related to their learning. The children chose words to describe their feelings on making a mistake (they pick negative words, including 'devastated' and 'frustrated'), followed by words to illustrate how teacher 'feedback' and help makes them feel (positive words, including 'inspired', 'delighted' and 'phenomenal'). The children's choice of the 'right' emotions illustrate that they are both understanding of and compliant with the messages being disseminated. Previous school assemblies and lessons on resolution have given these eight year olds a fairly secure idea of what the word means, what sort of words and phrases one should use to discuss it, and what sort of behaviour and feelings are desired. By the time I observed them, the children were fluent in their use of these phrases.

Other lessons on different values focused on the children's social behaviours, what Suissa (personal communication) calls their 'other-regarding ethical virtues'. For example, in another lesson on kindness and together-ness, the Y6 children (10/11 years old) chanted a mantra which started 'I am strong, I am unique...' and were then given slips of paper with a randomly allocated child's name. They were enjoined to write something complimentary about that child. The children deliver 
their pieces of paper to much smiling and laughter as they read what has been written about them. Most appeared happy, although one child pointed out that he was disappointed to be told only that he is good at a particular playground game. Variations on this exercise are not unknown in primary school classrooms, and clearly designed to encourage a sense of collectivity, a sense of the classroom being a safe and warm space where people are kind towards each other. Such intentions are surely praise-worthy. However, it is hard to overlook the potential for 'surface acting' (Hochschild 1983, Hemming 2015), and the manufactured nature of the emotion behind the compliments, although the responses (of both pleasure and slight disappointment) seemed genuine. In this sense, the child who told the boy he was good at the playground game could be seen as refusing a move into false enthusiasm, sticking to a positive, but emotionally neutral, comment.

As they leave their classroom and go to lunch, these children pass the class noticeboard highlighting the names of particular pupils who displayed the current value. On the stairs and in the playground, they pass displays illustrating one or all of the school values, some prepared by the children themselves, and others that are large, permanent display boards. The school's visual presentation of its values is stylised, distinctive and repeated around the school site (details not given to preserve anonymity). The iconography, and the fluent and ritualised nature of the children's responses, the way in which the values permeate school life (the school does not have rules for example, the values provide a behavioural framework), the coherence and pervasiveness of the messages generated by the institution and then rehearsed by pupils, all work to suggest the atmosphere of a traditional faith community - minus the theology. Formally and explicitly, religion plays little part in the school's ethos. The values were developed originally by the head-teacher as a way of framing behaviour within the school, the behaviour of both the children and the adults. They are, however, intended as more than a behaviour management device, but rather as explicit encouragement of 'the qualities that we think are going to help you in life' (head-teacher). The resemblance to a religious community which I identify was not the result of deliberate intention by the school leadership. 
Similarly, Hemming, in his assessment of values education at two primary schools, one a Catholic school and one a non-faith school identifies considerable areas of commonality between the two. He argues that his fieldwork illustrates 'the central premise that religion can be "located" within apparently "secular" places' (2015 p.119). In support of this, he notes that the values promulgated - 'an understanding of the moral values of right and wrong, tolerance, respect, caring and honesty' (2015 p.117) - were similar at each school, as were the practices and techniques, with only their framing differing: Gospel teaching at the Catholic school, and PSHE (Personal, Social, Health and Economic education) teaching at the secular school. Hemming concludes that these commonalities are indicative of post-secularism. He further notes the 'rather mundane and everyday nature of the religious realities in the [non-faith] primary school' in terms of the content of assemblies, the values disseminated, the identities of the pupils and staff, thereby illustrating the subtle, unspoken, and taken-for-granted ways in which Christianity permeates secular school culture. The intensity of Southern's efforts to develop pupils socially and emotionally (the weekly class lessons, the assemblies, the posters and displays around the building, the frequent staff references to the school values, the reward system) is unusual compared to the other schools in my research, but such wholeschool cohesive approaches are encouraged by the Jubilee Centre for Character and Virtues at the University of Birmingham, the Values-based Education (VbE) movement, and other similar programmes.

\section{Pastoral power?}

Such explicit work on social and emotional development has been criticised for its neo-liberal emphasis on the development of the self-sufficient, self-responsible individual - witness, the children working on themselves, seeking to improve, taking responsibility for their own social and learning behaviours (e.g. Ecclestone 2012, Ecclestone \& Lewis 214). The complex and close engagement between the operation of neoliberal markets and the deployment of particular emotional competencies has been discussed by many scholars (e.g. Ball 2003, Giroux 2005, D'Aoust 2014). Such work with Southern School's population of largely workingclass, frequently poor, black and minority ethnic pupils could be understood as 
working to 'align individual conduct with neoliberal capital's double injunction of market rationality and social responsibility' (Vrasti and Montsion 2014 p.336). The school's mission is presented using the language of excellence and aspiration, as the children 'acquire much-needed emotional competencies to succeed inside global capitalism' (D’Aoust 2014 p.273).

Thus, values education can be understood as a technology of government of the population, producing willing subjects. Foucault's conception of pastoral power is useful for understanding the forms of power evoked by values education. This concept derives from the pastor developing "'a never-ending knowledge of the behaviour and conduct of the members of the flock he supervises" (Foucault $1982 \mathrm{p}$. 181)' (cited in Golder 2007 p.167). Perryman et al (2017) add relevant detail when they define pastoral power as 'a form of power' which,

'Cannot be exercised without knowing the inside of people's minds, without exploring their souls, without making them reveal their innermost secrets. It implies a knowledge of the conscience and an ability to direct it' (Foucault 1982:883). In schools [other forms of power such as] disciplinary power and 'the gaze' have not gone [..] However, pastoral power gives the subject responsibility for their own production (Perryman et al 2017 p.746).

Pastoral power is a precursor for 'modern systems of governmentality. This is a technique of political individualization - the production and conduct of governable identities' (Golder 2007 p.173), a form of government concerned with the political management of entire populations (Blake 1999 p.82). Bailey similarly argues that pastoral power had developed by the eighteenth century from its older, overtly religious form into a new form.

No longer concerned with securing the salvation of spiritual community in the afterworld, but about achieving the worldly happiness and vitality of the population [...] A 'happy' and healthy population - in other words, an ordered, civil, well-moraled, respectable, thrifty, and disciplined population - ensures 
that the state is strong and stable...Pastoral power is thus secularised (Bailey 2015 p.92, original emphasis).

Bailey's description seems to me to be an apt one for describing the play of power through values education. I am suggesting that the pedagogy of values education which seeks to work on and with children to develop particular values understood as social and emotional competencies can be understood as a technology of pastoral power. I am not suggesting a straightforward exercise of power by adults over children, as the concept of a pastor may seem to suggest. This would anyway not fit with Foucault's theorising of power as 'power is everywhere', and 'comes from everywhere' (Foucault 1998 p.93) and results not 'in a binary structure with "dominators" on one side and "dominated" on the other, but rather a multiform production of relations of domination" (Foucault 1980 p.142). Children are able, to some degree and in some situations, resist adult attempts to control them. In addition, the school leadership at Southern models a 'soft' form of control, placing a strong emphasis on adults modelling the school values in their behaviour towards each other and the children.

\section{Civic values?}

It is my contention that neither the promotion of British values, nor values education more generally, necessarily develop civic values. Concerning the latter, it is important to be clear that teachers' work at Southern, was not all inwarddirected, aimed at developing the individual. The children followed a programme of work on identity that included their identity as 'British' and as 'global citizens'. The older children had opportunities to learn about the conflict in Syria and refugee camps at Calais. Indeed, advocates argue that values education can and should include outward-looking 'citizen' activity. Arthur et al for example place civic virtue as one of four main types of virtue and defines it as 'the virtues necessary for engaged and responsible citizenship. They include service, citizenship and volunteering' (2017 p.11). Volunteering and charity fundraising are indeed fairly common activities in schools. However, the emphasis of the form of values teaching I observed at Southern was primarily on self-development, or how one should live, 
rather than social/political values concerning how we should organise our social lives together. For example, the ability to think critically could take the form of debating the nature of the school values, but these were not, that I saw, problematized. Euade (2016), for example, suggests discussion of respect, a common school value, and indeed a British value, could also include debating the possibility of excessive deference, or respect for those engaged in unlawful behaviour. Suissa (2015) similarly discusses resilience, suggesting that the question 'are there things we should not be resilient to?' should be discussed with students. However, the focus of values teaching/character education appears to be developing 'good' people rather than 'good' citizens (Suissa 2015), what Kisby (2017) calls 'personal ethics' rather than 'public ethics'. Kisby cites Rawls to describe the latter: 'where he sought to shift the question from: how should I live? to how can we live together in society given that there are different answers to the question: how should I live?' (2017 p.16)

Similarly, the promotion of British values does not appear to generate much explicit discussion of how can we live together, nor a view of politics as an on-going process of engagement with moral questions, rooted in human experience, such as to how to shape and organize society (Suissa 2015 p.113). Instead the promotion of British values in schools is dominated by the superficial celebration of apparently British artefacts, people and traditions. This offers an implicit message that those who do not follow those traditions or lifestyles are not 'British', a quietly exclusionary positioning. It is important to be clear that a focus on British cultural symbols was not the entirety of the responses from my case study schools, who had succeeded in many instances in their attempts to soften the nationalistic edges of the British values policy and absorb it into their existing practices (further discussed in Vincent 2017), but, as with values education more generally, there was a lack of clear engagement, discussion and debate around the British values.

\section{Conclusion}

This paper seeks to contribute to several different discussions in fields located within and between education, philosophy, and sociology. I have illustrated, with 
regard to the British values policy, how religion - Christianity and 'other' faiths explicitly and implicitly - works both through and against the state to influence the existing contours of education policy.

Despite the looseness of the British values policy, the current context - in which the signifier of 'Muslim' has become a potential hazard, a warning of possible, perhaps even probable, illiberality - cannot be overlooked as indicative of who is already 'British' and in possession of liberal values, and who requires assimilation into that identity. I suggested, along with other commentators, that through Prevent and British values, the state's gaze intensifies when Muslim populations and schools are considered (Holmwood \& O'Toole 2018, Saeed 2017). I then illustrated with reference to values education at Southern School, how religion, particularly Christianity, although de-theologised, implicitly shapes normative understandings of values so that its influence can be traced in apparently secular places.

On the surface, values education, and the British values policy in particular with its focus on liberal values, could be understood as having the potential to act as an entry point and encouragement to discuss issues of belonging, exclusion, government and citizenship, to encourage children to think about how we can best live together as a diverse population. However, to date, my data illustrates that neither form of values education generally develop this type of civic virtue. Values education as illustrated here focuses on the development of inward-directed social and emotional competencies, and the enactment of the British values policy illustrates the scope of the content with which many teachers feel comfortable. Given the performative policy context dominating schools driven by targets and results, encouraging civic virtue may only seem possible within limits of the known and the familiar (such as volunteering activities). Thus, arranging opportunities for children and young people to critically engage with issues around values, difference and equality is an option only a few teachers will feel able to take up. 


\section{References}

Alam Y. \& Husband, C. (2013) Islamophobia, community cohesion and counterterrorism policies in Britain, Patterns of Prejudice, 47:3, 235-252.

Appiah, K. A. (1994) Identity, authenticity, survival: multi-cultural societies and social reproduction, in Gutmann, A. (ed) Multiculturalism. Princeton, NJ, Princeton University Press.

Arthur, J. (2015) Extremism and neo-liberal education policy: A contextual critique of the Trojan Horse Affair in Birmingham Schools, British Journal of Educational Studies 63, 3: 311-328.

Arthur, J., Kristjansson, K.,Harrison, T., Sanderse, W., \& Wright, D. (2017) Teaching Character and Virtue in Schools. London, Routledge.

Bailey, P. L. J. (2015). " Teach First" as a dispositif: towards a critical ontology of policy and power. Unpublished Doctoral dissertation, University of London.

Ball, S. (2017) Foucault as Educator. Cham, Springer International

Ball, S. J., Maguire, M. \& Braun, A., (2012) How Schools Do Policy: Polcy Enactments in Secondary Schools. London, Routledge.

Ball, S.J. (2013a) The Education Debate. Bristol, Policy Press

Ball, S.J. (2013b) Foucault, Power and Education. London, Routledge.

Ball, S.J., (2003) The teacher's soul and the terrors of performativity, Journal of Education Policy, 18, 2: 215-228

Ben-Porath, S. (2013) Deferring virtue: The new management of students and the civic role of schools, Theory and Research in Education 11, 2: $111-128$. Blake, L. (1999) Pastoral power, governmentality and cultures of order in nineteenth-century British Columbia, Transactions of the Institute of British Geographers 24, 1: 79-93 24,

Byrne, B. (2016) Testing times: The place of the Citizenship Test in the UK immigration regime and new citizens' responses to it, Sociology 51, 2: 323-338 Cameron , D. (2011) Prime Minister's King James' Bible Speech. https://www.gov.uk/government/news/prime-ministers-king-james-bible-speech Cantle T., (2001) Community Cohesion: Report of the Independent Review Team (The Cantle Report). London, Home Office. 
Casanova, J. (2006) Rethinking secularization: A global comparative perspective Hedgehog Review, 8, 1-2: 7-22.

Coppock, V. and McGovern, M. (2014), 'Dangerous minds'? Deconstructing counterterrorism discourse, radicalisation and the 'psychological vulnerability' of Muslim children and young people in Britain. Children \& Society, 28: 242-256.

Cranston, N., Kimber, M., Mulford, B., Reid, A., \& Keating, J. (2010), Politics and school education in Australia: a case of shifting purposes, Journal of Educational Administration, 48, 2: 182 - 195.

D'Aoust, A.-M. (2014) Ties that bind? Engaging emotions, governmentality and neoliberalism: Introduction to the Special Issue, Global Society 28, 3: p.267-276.

Dillon, M. (2012) Jurgen Habermas and the post secular appropriation of religion, in P. Gorski, D. Kyuman Kim, J. Torpey, J. VanAntwerpen (eds) The Post-Secular in Question: Religion in Contemporary Society, New York: NYU Press.

Eaude, T. (2016) New Perspectives on Young Children's Moral Education. London, Bloomsbury.

Ecclestone, K. \& Lewis, L. (2014) Interventions for resilience in educational settings: challenging policy discourses of risk and vulnerability Journal of Education Policy, 29, 2: $195-216$

Ecclestone, K., (2012) From emotional and psychological well-being to character education: challenging policy discourses of behavioural science and 'vulnerability'. Research Papers in Education, 27, 4: 463-480.

Foucault, M (1998) The History of Sexuality: The Will to Knowledge: v. 1 London, Penguin

Foucault, M. (1983): Discourse and truth: the problematization of Parrhesia. Six lectures given by Michel Foucault at the University of California, Berkeley. Retrieved from http://foucault.info/documents/parrhesia

Foucault, M. (1982) The Subject and Power, Critical Enquiry 8, 4: 777-795.

Foucault, M. (1980) Power/Knowledge: Selected Interviews and Other Writing. New York, Pantheon Books

Garbaye, R. and Latour, V. (2016) Community and citizenship in the Age of Security: British policy discourse on diversity and counter-terrorism since 9/11, Revue 
Française de Civilisation Britannique. French Journal of British Studies XXI(XXI-1). Online at https://rfcb.revues.org/867

Giroux, H. (2005) The terror of neoliberalism: Rethinking the significance of cultural politics College Literature 32, 1: 1-19.

Goldberg, D. (1993) Racist Culture. Oxford, Blackwell.

Golder, B. (2007) Foucault and the genealogy of pastoral power, Radical Philosophy Review, 10, 2: 157-76.

Gutmann, A. (1994) Democratic Education. Princeton, NJ, Princeton University Press.

Habermas, J. (2008) Notes on a post-secular society, New Perspectives Quarterly 25, 4: $17-29$

Hemming, P. (2015) Religion in the Primary School. London, Routledge.

Holmwood, J. \& O'Toole, T. (2018) Countering extremism in British schools? The truth about the Birmingham Trojan Horse Affair. Bristol, Policy Press.

Home Office (2011) Prevent Strategy. London, HMSO.

Horton, J. (1996) 'Toleration as a Virtue' in Heyd, D. (ed.) Toleration, Princeton University Press, Princeton, New Jersey

Husband, C. \& Alam, Y (2011) Social Cohesion and Counter-Terrorism: A Policy Contradiction? Bristol, Policy Press.

Isin, E. (2004) The neurotic citizen, Citizenship Studies, 8, 3: 217-235

Jerome, L. and Clemitshaw, G. (2012) Teaching (about) Britishness? An investigation into trainee teachers' understanding of Britishness in relation to citizenship and the discourse of civic nationalism, Curriculum Journal 23, 1: 19-41.

Jivraj, S. (2013) Interrogating religion: Christian/secular values, citizenship and racial upliftment in governmental education policy, International Journal of Law in Context 9, 3: 318-342.

Kisby, B. (2017) 'Politics is ethics done in public': Exploring linkages and disjunctions between citizenship education and character education in England. Journal of Social Science Education 16, 3: 8-21

Mac an Ghail, M. \& Haywood C. (eds.) (2017) Muslim Students, Education and Neoliberalism. London, Palgrave Macmillan 
Maccarini, A-M (2016) On character education: Self-Formation and forms of life in a morphogenic society, Italian Journal of Sociology of Education. Available at: http://ijse.padovauniversitypress.it/2016/1/3.

Macedo, S. (2000) Diversity and Distrust. Cambridge, MA. Harvard University Press. McClain, L. (2001) The Domain of civic virtue in a good society: Families, schools, and sex equality, Fordham Law Review 69, 1617-1666.

Meer, N. (2010) Citizenship, Identity and the Politics of Multiculturalism: The rise of Muslim consciousness, Basingstoke: Palgrave Macmillan.

Mellor, P. (2004) Religion, Realism and Social Theory. London, Sage.

Morgan, G. (2016) Global Islamophobia: Muslims and Moral Panic in the West London, Routledge.

O’Toole, T, Meer, N, DeHanas, DN and Jones, SH (2016) Governing through Prevent? Regulation and contested practice in state-Muslim engagement Sociology, 50, 1: 160-177.

Perryman, J., Ball, S., Braun, A. \& Maguire, M. (2017) Translating policy: governmentality and the reflective teacher, Journal of Education Policy 32, 6: 745756.

Poole, E. (2016): Constructing 'British Values' within a radicalisation narrative, Journalism Studies. Online before print

Razack, S. (2008) Casting Out: The Eviction of Muslims from Western Law \& Politics. Toronto, University of Toronto Press.

Saeed, T. (2017) Muslim narratives of schooling in Britain: From 'Paki' to the 'Would be Terrorist', in M. Mac an Ghail, \& C. Haywood (eds.) Muslim Students, Education and Neoliberalism. London, Palgrave Macmillan

Scanlon, T., ( 2003) The difficulty of tolerance: essays in political philosophy. Cambridge, Cambridge University Press.

Smargorinsky, P. \& Taxel, J., (2010) The Discourse of Character Education. London, Routledge.

Stoler, A., (1995) Race and the education of desire: Foucault's history of sexuality and the colonial order of things. Durham, NC., Duke University Press.

Struthers, A. (2017) Teaching British Values in our schools, Social \& Legal Studies 26, 1: 89-110. 
Suissa, J. (2015) Character education and the disappearance of the political, Ethics and Education 10, 1: 105-117.

Tan, C. and Tan, C. (2014) Fostering social cohesion and cultural sustainability: Character and citizenship education in Singapore, Diaspora, Indigenous, and Minority Education 8, 4: 191-206

Vanderbeck, R. and Johnson, P. (2016) The Promotion of British Values: Sexual orientation equality, religion, and England's schools, International Journal of Law, Policy and the Family 30, 3:292-321.

Vincent, C. (2017) Cohesion, citizenship and coherence: The British values policy in schools. Paper presented at 'Fundamental(ly) British Values' conference. November $17^{\text {th }}$ at UCL.

Vrasti, W. and Montsion, J.M., (2014) No good deed goes unrewarded: The values/virtues of transnational volunteerism in neoliberal capital. Global Society, 28, 3: 336-355.

Walker, D., Roberts, M., \& Kristjánsson, K. (2015) Towards a new era of character education in theory and in practice, Educational Review, 67:1, 79-96.

Winton, S. (2007) Does character education really support citizenship education? Examining the claims of an Ontario policy. Canadian Journal of Educational Administration and Policy, 66, 1-24. 